\title{
Study on the Social Structure Change of the Mainland Immigrants in Open Pilot Area of Changjitu
}

\author{
Taoran Chen $^{1, \text { a }}$ \\ ${ }^{1}$ College of History and Culture, Beihua University, Jilin 132013, China. \\ ataoran_chen@126.com
}

Keywords: Immigrants of inside the Shanhaiguan Pass, Changjitu open pilot area, cities modernizing.

\begin{abstract}
The immigrants of inside the Shanhaiguan Pass entering into the Changjitu Open Pilot Area, not only has provided the human resources for the regional economy development, promoted agriculture, commerce and industry development, has laid the population and the economic foundation for the urbanization of the Changjitu Open Pilot Area. The immigration entry even directly promoted the land relations that depend on original administration and management system in the Changjitu Open Pilot Area disintegrating, thus promoting the administration modernizing in the Changjitu Open Pilot Area and the cultural ecology further evolution. From this point, the immigration not only directly promoted the urbanization of the Changjitu Open Pilot Area; moreover it has accelerated cities modernizing.
\end{abstract}

\section{Introduction}

Changjitu development herald Area lay Modern urban population structure is long and the Immigration Qing Dynasty to the early surge. Notwithstanding the previous mid-Qing Han Chinese immigrants arrived Changjitu Development Pilot Area, but the Immigration in the early Qing Dynasty into the land is a "banned land" of the Qing government, and later entered again in "the ban of" clean government into Changjitu immigration in the pilot area of the development status and instant into a "refugee", could not escape the fate of being expelled. Due to increased immigration followed, the Qing government to expel "Do not fear born minor" and "in situ placement", but its scope of activities is limited to a small area in southern Changjitu Development Pilot Area. Until the end of the Qing, in a particular historical context frontier crisis, the Qing government, the Northern Government and the Local Northeast Government regarded the cause of immigrants in an extremely important position, and actively promote the cause of immigrants were encouraged support for a large number of immigrants entering Changjitu Development pilot area to create all favorable conditions, which is no doubt the immigration in the formation of a powerful "pull." Coupled with the great natural disasters in North China "push", immigrants began to move his family, Seasonal migrants began to decrease, not only immigrant settlers increased, and more women and children with the influx of young immigrants Changjitu development pilot area of tension in the region the formation of a stable population structure.

Enter Changjitu Development Pilot Area of working age immigrants based immigration, a high density of young immigrants Changjitu Development Pilot Area provides a number of, endless stream of labor resources, promoting economic development in the region, despite migrants constitute vocational agriculture-based immigration, the nature of labor migrants are mostly ordinary, but has not yet developed a relatively wide wrap boundless, Changjitu development pilot Area plain wilderness, this is undoubtedly the most appropriate human resources. Modern history has repeatedly proved that regional economic development, although the flow and supply of labor belonging to the flow of capital, but the lack of labor, capital, it is difficult to play its due role, and then will change the flow of investment, industrial and commercial constraints and thus restricting economic development. Therefore, the degree of richness of the labor force and its configuration of resources for economic development of any country and region is very important. Qing Dynasty is because of the continuous influx of young immigrants with the customs, agriculture first and then other industries to provide the 
necessary labor, to ensure low-cost, high rate of return of various industries, so as to promote the sustained regional capital investment growth, so Changjitu economic development pilot area to follow the expansion of arable land, food production continues to increase, and thus the formation of agricultural commodity distribution market businesses have been greatly developed, and quickly became the region's rapid economic development in the late Qing Dynasty.

\section{Late Qing Dynasty Changjitu Development Pilot Area Migrants}

Early Qing Changjitu Development Pilot Area up Ken immigrants a year during the Ming and Qing Dynasties, living in Changjitu Development pilot area are mostly engaged in fishing or hunting and nomadic ethnic minorities, tiger Erka, East China Sea and other Waer Ka tribes living in the eastern region of northeastern Hoche, Evenki, Daur, Oroqen. "Soren tribes' living in the northwest of the vast region, southwest of the Mongolian ministries. After the establishment of the gold regime, constantly pacify the conquered and appeasement policies under Nurhachu, an end to "from the northeast seaside Okhotsk Sea, until the northwest seaside Lake Baikal, during causes the dog to make the state deer, Waqf black fox, sable of , the fight does not matter species living of hunting and fishing folk, tribal E Lute, and turn hard Heyuan, far near countries, in the surrender. " Ming Noor stem Secretary of jurisdiction throughout the whole after the Qing regime under Kim. For the operational needs of the Ming Dynasty, in the decades of the seventeenth century, the Qing rulers continued to build the Liao Shen Area population, northeast of the northern part of northeast Heilongjiang River and the southern region of the Changbai Mountain area depopulated, Changjitu development pilot Area almost depopulated.

This is just the first step in the assembly in the southern region northeast of the minority Changjitu Development Pilot Area, then there will be the minority with the Qing rulers "entry from the dragon." Junji dynasty, the Qing dynasty as bad Dole captured Beijing and Harbourside, living in the southern region of Northeast Manchu rulers of the Qing ethnic populations with Xin family move into a sharp decline in the Liao Shen population, and Taiji dynasties ruled Nurhachu by operating for decades in the southern region of Northeast, except for a few military areas to keep some Banners soldiers stationed outside the Northeast southern suddenly become "desolate people thin, depressed livelihood," Ye no farmer, no way merchants, originally uninhabited the northeast region has become more desolate. Coupled with the southern region of Northeast Manchu and Chinese battle after twenty-five years of the Late Ming, barren land, farming pause. At that time, the Qing court to Mukden prefect Zhang Shangxian in "fundamental situation sparse" that "remote hamlet waste fort, defeated tile moldering, Woyeqianli have no land, nothing can rely." Tellingly, after the Manchu Inland northeast lost areas depressed condition.

\section{Initially laid urban population structure Changjitu Development Pilot Area}

Modern Immigration in the Northeast into the exhibit from south to north, gradually moving from west to east, the development level of the situation. Before the middle of the Qing, the Qing court banned due to the policy, the Immigration moved into range is limited to the southern region of Northeast. Vast areas of the Northeast, especially in northern Changjitu Development Pilot Area remains outback. But a small part of the Immigration in the old Guan Dao and can be funded along navigable rivers north to Changjitu Development Pilot Area west Area that previously described "refugee." Xianfeng dynasty, the Qing government Rescinding the Prohibition fallow, Changjitu Central Region Development Pilot Area Hulan River plain that is to be developed, Qing Dynasty, such as the Immigration waves rush over to the North, Changjitu Development pilot area development into the new historical period. Qing Dynasty Changjitu Development Pilot Area for the main areas of immigrant absorption has said Xiang, the following case study of the Northeast Immigration basically represent Changjitu Development Pilot Area increased permanent immigration trend. Early Changjitu Development Pilot Area immigrant farmers due to Chinese traditional love love home soil, "homebody" Cultural Psychology, after its home "mentality often in a free state." 
Early immigrants, only the Northeast as a living place, not as a home, obviously we want to settle down in the Northeast, but always thought home in customs, roots customs, immigration still talking about it often is "high, the falling tree, roots "," parents do not travel to distant lands, "so-called" homebody, Lebanon's resistance, with flesh attached, human wish also. " Immigration old, and still return to their homeland with dignity, unwilling to throw bones in a foreign land, this mentality is deeply rooted in our nation's ideological consciousness is a reflection of thousands of years of tradition consciousness. It is this traditional role of psychological factors hard to leave their native land, prompting a large number of migrants returned under possible conditions. "Ta Kung Pao" contains "In our country people deep sense of family, the love of the village cut, the life of Gou have enough food and clothing were also not want to travel to distant lands, his or lived far away who also have spring and autumn return, namely as Lu people, each in after the New Year, the trend to go to customs, engaged in agro-business, a little savings to late fall, will return home. "

\section{Immigration and Changjitu Development Pilot Area Economic Structure Evolution}

Modern large number of the Immigration enter Changjitu Development Pilot Area engaged in agriculture, deforestation, mining, dock transportation work for the Changjitu herald Area economy provides ample labor force, thus contributing to Changjitu Development Pilot improve food production and development of land, the food needs of local residents after the meet, also invested in a large number of Sinotrans and agricultural products processing industry, agro accelerate the commercialization process. "It immigrant labor to the lower half of the century, only to become one of northeast China's most high-yield agriculture industry's most developed regions. "' Speed Eastern Province colonial enterprise and the development of the productive forces in the world can be called first before the century last years, Eastern Province, where the still uncivilized, the natural Fuyuan, solid long Visible in the eyes and ears as well. and this is a change the most prosperous region of transactions in goods, and in the world economy accounts for an important sector of the position. Thus, agriculture, commerce, crafts three mutual promotion and common development, constitute the basis for economic development pilot area Changjitu towns rise.

\section{Immigration and Changjitu Development Pilot Area business, development of industrial economy}

The Immigration into the Northeast, not only to provide a general labor Northeast development, also a considerable number of the Immigration engaged in trade and the industries and other economic activities, Traders membership do not primarily in Shandong, Hebei, Shanxi and other provinces, mainly indigenous traders are small, so-called "straight, Shandong, Shanxi, Henan, Jiangsu, Zhejiang, Fujian, Guangzhou and other places of merchant capital investment remaining in Manchuria, and straight, Shandong, Shanxi provinces, the forces of the province in the economy alone thick." According to Lu Yu investigation, in Shandong Laiyang County in the Republic of humans "Northeast", it was to the northeast of the country to work in business, the total number of "Northeast" in. For more than Laoting Hebei businessman, Changli, Luan County, Funing Jidong and other four counties, in addition to Shandong, Hebei businessman, the Shanxi merchants footprint is all over the Northeast, the "thick huge profits, not store deacon a hybrid alien , each store has a presence in the city. "Kannai businessman came to the northeast, engaged in various business activities, some of them set up shop in the northeast shop, business shoes, clothing, medicine and other necessities of life supplies, and some engaged in long-distance traffic, the customs and exchange of goods outside the customs Have the Republic of China years, with the emergence of the Northeast land development and deepening of the grain trade, grain stack operators gradually increased, and with frequent trade activities and active exchange activities, operating pawnshops, banks Zheyi minority. This is a change the most prosperous region of transactions in goods, and in the world economy accounts for an important sector of the position. Thus, agriculture, commerce, crafts 
three mutual promotion and common development, constitute the basis for economic development pilot area Changjitu towns rise.

\section{Urbanization and urban migration and development pilot Area Changjitu Modernization}

"Towns are developing the productive forces to a certain historical stage, we experienced a settlement villages to towns process that is the stage of the city's origins," and also in the process of demarcation of urban exterior space structure. The arrival of the Immigration is a prerequisite for Changjitu pilot Area of urbanization, which appears someone has been described in the image of the town: "Just a wasteland reclamation, when the initial influx of immigrants occupied the most fertile land, a shack there, between the Island and the island there are a lot of folders shortage, and later emigrated and continue to influx clip shortage disappeared, and villages there, a piece of wasteland into an oasis. with active commodity economy, speed up the flow of logistics operation, land and sea traffic started to flourish in the commercialization of agricultural products of high reclamation area, roads and shipping terminal in goods distribution center, one new town developed. "

Modern Changjitu Development Pilot Area Urban Development two major themes: First, urbanization modern movement, the second movement is the modernization of the town. The former is prominent in urban development and size of the amount, which reflects the changes of the town in terms of quality. Modernization of urbanization and modern urban development Changjitu pilot area is to promote interaction occurs, with the urbanization and modernization occur, along with modernization and urbanization expand. Whether urbanization or urban modernization, and its main key factor is "human."

Immigration in general appear as a "person" concept, it has changed the nature of the object migration itself has become the main ethnic Changjitu Development Pilot Area. In Changjitu Development Pilot Area Development earlier Hulan area, for example, to 1909, the area that is the Han population has total population of $98.8 \%$. To the end of the Qing Dynasty, in the case of deterioration of the living environment in North China, conservatively estimated that at least 3 million immigrants to enter the customs Changjitu Development Pilot Area, mostly immigrant moved with his family, such as a flood wave of the influx Changjitu Development pilot area. Visible, the Immigration implanted at this time is neither as individuals, nor the beginning of the seasonal migration to the northeast when, but for permanent residence: not only the formation of the absolute number of advantages, but also the formation of a stable region population structure.

\section{Acknowledgements:}

Jilin Province Philosophy and Social Science Fund Project Planning "Changjitu region and the Immigration and Social Structure"[2014B82]

\section{References}

[1] Jilin Province Archives: "Qing Dynasty, Jilin Selected Historical Data" (Edict • Memorials), internal 1981 edition.

[2] "Selected Historical Archives of Heilongjiang in Qing Dynasty" (Guangxu eight and fifteen years), Heilongjiang People's Publishing House, 1986 edition.

[3] First Historical Archives of China Ministry of Manchu, Heilongjiang Academy of Social Sciences Institute of History: "History of Qing Dynasty Heilongjiang profile Selected text)) (Guangxu year 2017), Heilongjiang People's Publishing House, 1988 edition.

[4] Jilin Province Archives: "Jilin general Yamen file" 1 (6-1) -41, 123, 304, 1 (6-4) -10 820.

[5] Second Historical Archives of China: "Republic of China History Archives compilation" third series, Jiangsu ancient books published in the 1994 edition. 
[6] Chinese First Historical Archives: "Guta deputy general bureaucratic files" Fonds No. 1-430, 31-8500. 